\title{
PENGEMBANGAN MEDIA POSTER SEBAGAI SUPLEMEN PEMBELAJARAN FISIKA MATERI TATA SURYA
}

\section{DEVELOPMENT OF THE POSTER MEDIA AS A PHYSICAL LEARNING SUPPLEMENT OF SOLAR SYSTEMS}

\author{
Ajo Dian Yusandika ${ }^{1}$, Istihana ${ }^{2}$, Erni Susilawati ${ }^{3}$ \\ 1,2,3 Pendidikan Fisika, UIN Raden Intan Lampung, Indonesia \\ e-mail: ajodian@radenintan.ac.id
}

Diterima: 17 September 2018. Disetujui: 15 Oktober 2018. Dipublikasikan: 29 November 2018

\begin{abstract}
This study aims to develop poster media and find out the feasibility of this learning media. This research uses research and development methods or Research and Development $(R \& D)$ conducted in three schools. The development procedure follows the Borg and Gall procedure which can be done more simply by involving 10 main steps, but the researcher only limits the seven stages in this study. The technique of collecting data in this study was using a questionnaire. Based on the results of data analysis after the product was validated by media and material expert validators, the final product produced fulfilled the eligible criteria with an average score of media experts at $89 \%$, material experts at $85 \%$, the attractiveness of students by $83 \%$ for the trial small group of $82 \%$ and educator responses of $81 \%$. The poster media is worthy of being used as a medium for learning physics.
\end{abstract}

\begin{abstract}
Abstrak: Penelitian ini bertujuan untuk mengembangkan media poster dan mengetahui kelayakan media pembelajaran ini. Penelitian ini menggunakan metode penelitian dan pengembangan atau Research and Development (R\&D) yang dilakukan di tiga sekolah. Prosedur pengembangan mengikuti prosedur Borg and Gall yang dapat dilakukan dengan lebih sederhana dengan melibatkan 10 langkah utama, tetapi peneliti hanya membatasi pada tujuh tahapan saja pada penelitian ini. Tehnik pengumpulan data dalam penelitian ini adalah dengan menggunakan angket. Berdasarkan hasil analisis data setelah produk divalidasi oleh validator ahli media dan materi, produk akhir yang dihasilkan telah memenuhi kriteria layak dengan skor rata-rata dari ahli media sebesar $89 \%$, ahli materi sebesar $85 \%$, hasil kemenarikan peserta didik sebesar $83 \%$ untuk uji coba kelompok kecil sebesar $82 \%$ dan tanggapan pendidik sebesar $81 \%$. Media poster sudah layak digunakan sebagai media pembelajaran fisika.
\end{abstract}

(ㄷ) 2018 Unit Riset dan Publikasi Ilmiah FTK UIN Raden Intan Lampung

Kata kunci : Media Pembelajaran, Poster, Tata Surya.

\section{PENDAHULUAN}

Pendidikan adalah suatu proses dalam rangka mempengaruhi peserta didik agar dapat menyesuaikan diri sebaik mungkin terhadap lingkungannya dengan demikan akan menimbulkan perubahan dalam dirinya yang memungkinkannya untuk berfungsi dalam kehidupan masyarakat. Pendidikan merupakan bagian terpenting dalam kehidupan manusia (Widayanti \& Yuberti, 2018), pendidikan sebagai suatu upaya yang sistematis berencana dan berkelanjutan tentu berupaya optimal untuk mencapai tujuan-tujuan pendidikan (Anggareni, Ristiati, \& Widiyanti, 2013).

Dari definisi tersebut berarti bahwa pendidikan sebagai suatu wadah dalam proses pembelajaran. Bagi seorang pendidik diharapkan dapat menyampaikan proses pembelajaran dengan menggunakan media pembelajaran yang mudah dimengerti 
dan menarik sehingga mudah dipahami, perkembangan media pembelajaran yang mampu mengolah, mengemas, menampilkan dan menyebarkan media pembelajaran, sehingga proses pembelajaran akan lebih menarik.

Media atau alat dan fasilitas pembelajaran yang belum dimanfaatkan secara maksimal oleh pendidik misalnya kliping, buku teks, alat praktikum, dan lain sebagainya. Hal itu dilakukan karena media pembelajaran merupakan perantara atau pengantar pesan (Wena, 2012), yang dipergunakan pada saat proses pembelajaran, pada saat proses pembelajaran membuat peserta didik sulit mengerti dengan materi yang diajarkan. Untuk mengatasi masalah tersebut pendidik perlu mengembangkan media pembelajaran yang sesuai dengan kebutuhan peserta didik misalnya dalam penggunaan media pembelajaran poster.

Media pembelajaran poster merupakan salah satu media yang terdiri dari lambang atau kata simbol yang sangat sederhana, poster juga sebagai kombinasi visual dari rancangan yang kuat, dengan warna dan pesan dengan maksud untuk menangkap perhatian peserta didik (Rizawayani, Sari, \& Safitri, 2017). Dengan media pembelajaran poster dapat memberikan nuansa belajar yang menarik dan efektif, dalam pembelajaran tata surya dengan poster dapat dilakukan di dalam maupun di luar kelas, dengan fungsi yang dapat disesuaikan dengan kebutuhan baik sebagai suplemen (tambahan), komplemen (pelengkap), ataupun subtitusi (pengganti) atas kegiatan pembelajaran di dalam kelas yang selama ini digunakan (Putri, Jampel, \& Suartama, 2014). Belajar yang demikian dapat memberikan kesenangan tersendiri untuk peserta didik, sehingga materi yang sebenarnya sulit menjadi mudah bagi peserta didik.

Menanggapi hal ini, diperlukan media pembelajaran alternatif yang dapat menarik minat mereka dalam membaca dan mempelajari materi tata surya, dimana pada materi tata surya terdapat banyak hapalan dan pemahan yang membuat peserta didik sulit memahami materi yang disampaikan. Penggunaan poster sebagai media, diharapkan peserta didik lebih mudah dalam memahami materi pembelajaran tata surya karena materi dalam poster memudahkan pendidik dalam menjelaskan materi dan mudah dipahami oleh peserta didik serta dibuat menarik dan lebih efektif agar peserta didik termotivasi untuk membaca, mempelajarinnya dan meningkatkan kemampuan siswa.

\section{LANDASAN TEORI}

Penelitian dan pengembangan atau yang kita kenal dengan istilah Research and Development $(R \& D)$, merupakan hal yang baru. Penelitian dan Pengembangan ( $\mathrm{R} \& \mathrm{D})$ adalah proses pengembangan dan validasi produk pendidikan (Sanjaya, 2017). Metode penelitian yang digunakan untuk menghasilkan produk tertentu dan menguji keefektifan produk tersebut supaya dapat berfungsi dimasyarakat luas (Sugiyono, 2016). Jadi penelitian pengembangan merupakan penelitian yang bertujuan untuk dihasilkannya produk tertentu.

Media pembelajaran adalah komponen strategi penyampaian yang dapat dimuati pesan yang akan disampaikan kepada siswa, baik berupa orang ataupun alat, atau bahan. Kata media berasal dari bahasa latin dan merupakan bentuk jamak dari kata medium yang secara harfiah berarti perantara atau pengantar. Media pembelajaran memiliki peranan penting dalam keberlangsungan proses belajar mengajar (Susilo, 2015). Kemudian di dalam media pendidikan memiliki kegunaan-kegunaannya yaitu:

1. Memperjelas penyajian pesan agar tidak terlalu bersifat verbalistis (dalam 
bentuk kata-kata tertulis atau lisan belaka).

2. Mengatasi keterbatasan ruang, waktu dan daya indera.

3. Penggunaan media pendidikan yang bervariasi dapat mengatasi sikap pasif anak didik (Sadiman \& Dkk, 2012).

Jadi kegunaan media pendidikan yaitu alat yang membantu proses belajar mengajar antara guru dan siswa agar lebih menarik yang tidak membuat siswa menjadi pasif dan malas untuk belajar.

Ciri-ciri umum yang terkandung pada setiap batasan tentang media adalah:

1. Media pendidikan memiliki pengertian fisik yang dewasa ini dikenal sebagai hardware (perangkat keras), yaitu sesuatu benda yang dapat dilihat. didengar, atau diraba dengan panca indera.

2. Media pendidikan memiliki pengertian nonfisik yang dikenal sebagai software (perangkat lunak), yaitu kandungan pesan yang terdapat dalam perangkat keras yang merupakan isi yang ingin disampaikan kepada siswa.

3. Penekanan media pendidikan terdapat pada visual dan audio.

4. Media pendidikan memiliki pengertian alat bantu pada proses belajar baik di dalam maupun di luar kelas.

5. Media pendidikan digunakan dalam rangka komunikasi dan interaksi guru dan siswa dalam proses pembelajaran.

6. Media pendidikan dapat digunakan secara massal (misalnya: radio, televisi), kelompok besar dan kelompok kecil (misalnya: film, slide, video, OHP), perorangan (misalnya: modul, komputer, radio tape/kaset, video recorder).

7. sikap, perbuatan, organisasi, strategi, dan manajemen yang berhubungan dengan penerapan suatu ilmu (Arsyad, 2013).

Jadi media yang digunakan untuk proses belajar mengajar yang dilakukan antar guru dan siswa banyak bentuknya, yaitu buku teks, alat peraga, papan tulis, proyektor, dan lain sebagainya.

Media adalah sesuatu yang digunakan untuk merangsang pikiran, peraasan, perhatian, minat peserta didik sedemikian rupa sehingga proses belajar terjadi, salah satu media yang dapat dimanfaatkan untuk meningkatkan kognitif peserta didik adalah media visualisasi. Media yang tepat dalam menerima informasi yang baik adalah media poster. Poster adalah kombinasi visual dari rangcangan yang kuat, dengan warna, dan pesan dengan maksud untuk menangkap perhatian. Poster juga disebut plakat, lukisan atau gambar yang dipasang sebgai media untuk menyampaikan informasi, saran, pesan, kesan, ide yang berfungsi untuk menarik perhatian, memperjelas sajian ide, mengilustrasikan atau menghiasi fakta yang mungkin cepat akan dilupakan. Poster merupakan alat pembelajaran untuk menambah kosa kata (Nurfajriyah, Aeni, \& Jayadinata, 2016).

Poster adalah media yang digunakan untuk menyampaikan suatu informasi, saran atau ide tertentu, sehingga dapat merangsang keinginan yang melihatnya, untuk melaksanakan isi pesan tersebut. Suatu poster yang baik harus mudah diinget, mudah dibaca, dan mudah untuk ditempelkan dimana saja (Sanjaya, 2017). Media poster dijadikan sarana untuk mengomunikasikan gagasan, evaluasi dan proyek inovasi klinis, kajian ini juga mengembangkan metode-metode pembelajaran yang bisa diterapkan dalam proses pembelajaran yang memanfaatkan media poster. Poster merupakan media gambar. Dalam dunia pendidikan poster (plakat, lukisan/gambar yang dipasang) telah mendapat perhatian yang cukup besar sebagai suatu media untuk menyampaikan informasi, saran, pesan dan kesan, ide dan sebagainya (Jannah, Serevina, \& Astra, 2016). 
Media pembelajaran poster dikatakan baik apabila memenuhi kriteria-kriteria tertentu, kriteria-kriteria yang mencangkup poster yaitu:

1. Tingkat keterbacaan (readability)

2. Mudah dilihat (visibility)

3. Mudah dimengerti (legibility)

4. Serta komposisi yang baik (Mayena, 2013).

Ada beberapa kelebihan dan kekurangan yang dimiliki poster yaitu :

a. Kelebihan poster

Poster juga memiliki kelebihan, yaitu harganya terjangkau oleh seorang guru atau tenaga pengajar. Dalam media poster memvisualisasikan pesan, informasi atau konsep yang ingin disampaikan kepada siswa. Poster menghadirkan ilustrasi melalui gambar yang hampir menyamai kenyataan dari sesuatu objek atau situasi (Mayena, 2013).

b. Kekurangan poster

Kekurangan poster adalah media ini tetap, diperlukan dalam keahlian bahasa dan ilustrasi dalam membuat poster, dapat menimbulkan salah tafsir, dari kata/kata simbol yang singkat, membutuhkan proses penyusunan dan penyebaran yang komplek dan membutuhkan waktu yang relatif lama dan jenis bahan yang digunakan biasanya mudah sobek, artinya gangguan mekanis tinggi, sehingga informasi yang diterima tidak lengkap.

\section{METODE PENELITIAN}

Penelitian dan pengembangan diadakan di SMP N 1 Wonosobo, SMP N 2 Wonosobo dan SMP PGRI 1 Wonosobo. SMP N 1 Wonosobo terdiri dari 5 kelas dengan jumlah 150 peserta didik, SMP N 2 Wonosobo terdiri dari 4 kelas dengan jumlah 100 peserta didik, SMP PGRI 1 Wonosobo terdiri dari 1 kelas dengan jumlah 26 peserta didik.

Pendekatan dan metode penelitian pengembangan berpedoman dari desain penelitian pengembangan media instruksional oleh Borg and Gall yang meliputi: 1) Potensi dan Masalah, 2) Pengumpulan Data, 3) Desain Produk, 4) Validasi desain, 5) Perbaikan Desain, 6) Uji coba produk, 7) Revisi produk, 8) Uji coba pemakaian, 9) Revisi Produk, 10) Produksi massal (Latifah, 2015). Produk yang dihasilkan berupa media poster sebagai suplemen pembelajaran fisika materi tata surya yang dapat dimanfaatkan oleh pendidik dan peserta didik dalam menumbuhkan minat pembelajaran IPA dikelas. Adapun pengembangan produk yang dilaksanakan pada penelitian ini hanya sampai pada tahap menghasilkan revisi produk, yaitu media poster sebagai suplemen pembelajaran fisika materi tata surya pada siswa kelas VII. Sehingga tidak sampai pada tahap uji coba pemakaian dan produksi masal produk. Untuk sampai pada tahap uji coba pemakaian dan produksi masal produk dapat dilakukan pada penelitian selanjutnya.

Kegitan awal sebelum melakukan pengembangan terhadap media poster sebagai suplemen pembelajaran fisika materi tata surya adalah penelitan pendahuluan. Penelitian pendahuluan berupa observasi awal dalam kegiatan pembelajaran yang dilakukan pada saat penelitti melaksanakan kegitan wawancara kepada peserta didik pada tanggal selasa 23 januari 2018 di SMP Wonosobo.

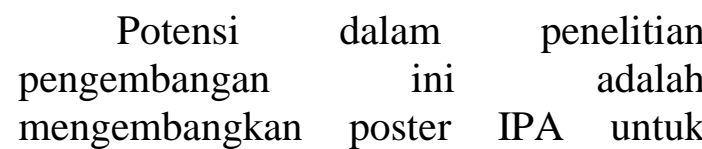
peserta didik SMP kelas VII pada materi tata surya. Potensi pengembangan produk tersebut untuk meminimalisasi permasalahan yang ada di kelas bahwa belum menggunakan media poster di SMP Negeri 1 dan 2 Wonosobo sehingga proses pembelajaran kurang menarik dan peserta didik kurang memahami materi yang disampaikan oleh peserta didik, tetapi di SMP PGRI 1 Wonosobo sudah 
menggunakan media poster namun poster yang digunakan kurang menarik sehingga peserta didik kurang termotivasi dan cepat merasa bosan.

Setelah potensi masalah diidentifikasi, selanjutnya dilakukan pengumpulan data dengan melakukan pengkajian terhadap materi Materi yang dipilih dalam penelitian ini adalah tata surya untuk peserta didik SMP kelas VII. Materi disesuaikan dengan peraturan menteri pendidikan Nasional Nomor 22 Tahun 2006 tentang Standar Isi Mata Pelajaran IPA untuk Sekolah Menengah Pertama. Kemudian ditentukan indikator dari materi yang dipilih. Dalam menentukan indikator, perlu dilakukan konsultasi dengan ahli materi agar didapatkan indikator yang tepat untuk nantinya dikembangkan sebagai ramburambu dalam pembuatan media pembelajaran. Selanjutnya dilakukan pengumpulan data dengan melakukan pengkajian terhadap perangkat pembuatan media.

Setelah dilakukan desain produk awal, selanjutnya produk dikonsultasikan kepada tim ahli yang terdiri dari ahli materi, ahli media dan guru IPA. Ahli materi mengkaji aspek sajian materi berupa kesesuaian materi dengan kurikulum (standar isi), kebenaran, kecukupan dan ketepatan isi produk. Ahli media mengkaji kaidah ketepatan animasi dan tampilan modul dengan karakteristik materi serta kesesuaian desain dengan tingkatan usia peserta didik. Ahli bahasa mengkaji atau memastikan bahasa yang digunakan baik dan benar. Penilaian dari guru bidang studi untuk menanggapi apakah modul sudah layak atau belum layak. Setelah produk awal sudah divalidasi oleh para ahli, maka dapat diketahui kekurangan dari poster dan kemudian melakukan revisi awal. Revisi awal sudah dilakukan kemudian divalidasi kembali oleh tim ahli untuk mengetahui kelayakan poster dan memberikan angket pada peserta didik mengenai tanggapan dari poster. Setelah desain produk divalidasi oleh ahli materi, ahli media dan guru SMP maka dapat diketahui kelemahan dan kekurangan dari poster tersebut. Kelemahan tersebut kemudian diperbaiki untuk menghasilkan produk yang lebih baik dan efektif.

Dengan uji coba produk uji coba produk merupakan bagian penting dalam penelitian pengembangan yang dilakukan setelah rancangan produk selesai. Uji coba produk dimaksudkan untuk mengumpulkan data yang dapat digunakan sebagai dasar untuk menetapkan tingkat efektifitas, efesiensi dan daya tarik dari produk yang dihasilkan. Untuk uji coba produk dilakukan dengan cara uji kelompok kecil, dan uji coba lapangan. Kemudian revisi produk sesuai dengan saran ide dari para ahli. Instrumen pengumpulan data menggunakan angket yang dianalisis menggunakan skala likert 1-5.

\section{HASIL DAN PEMBAHASAAN}

\section{Hasil Analisis Kebutuhan}

Hasil analisis kebutuhan yang dilakukan maka peniliti mendapatkan hasil utama dari penelitian dan pengembangan media poster sebagai suplemen pembelajaran fisika materi tata surya. Penelitian dan pengembangan dilakukan di tiga sekolah yaitu SMP N 1 Wonosobo, SMP N 2 Wonosobo dan SMP PGRI 1 Wonosobo. Responden dalam penelitian ini yaitu pendidik dan peserta didik kelas VII yang mendapatkan materi tata surya dalam penelitian ini peneliti menggunakan model penelitian dan pengembangan dengan mengadaptasi metode $R \& D$ Borg and Gall yang telah dimodifikasi oleh Sugiyono dari tahap 1 sampai tahap 7. Dalam penelitian dan pengembangan yang dilakukan menghasilkan produk media pembelajaran fisika berupa poster. 


\section{Hasil Desain Produk}

Berdasarkan data dan hasil pra penelitian atau observasi lapangan. Maka spesifikasi produk yang dikembangkan adalah media pembelajaran poster yang dapat membantu pendidik dan peserta didik dalam proses pembelajaran. Berikut adalah perancangan pengembangan media poster sebagai media pembelajaran fisika yang dikembangkan.

Berikut disajikan produk awal dan hasil revisi dari pembuatan media poster fisika materi tata surya.

Tabel Produk pengembangan media poster fisika materi tata surya

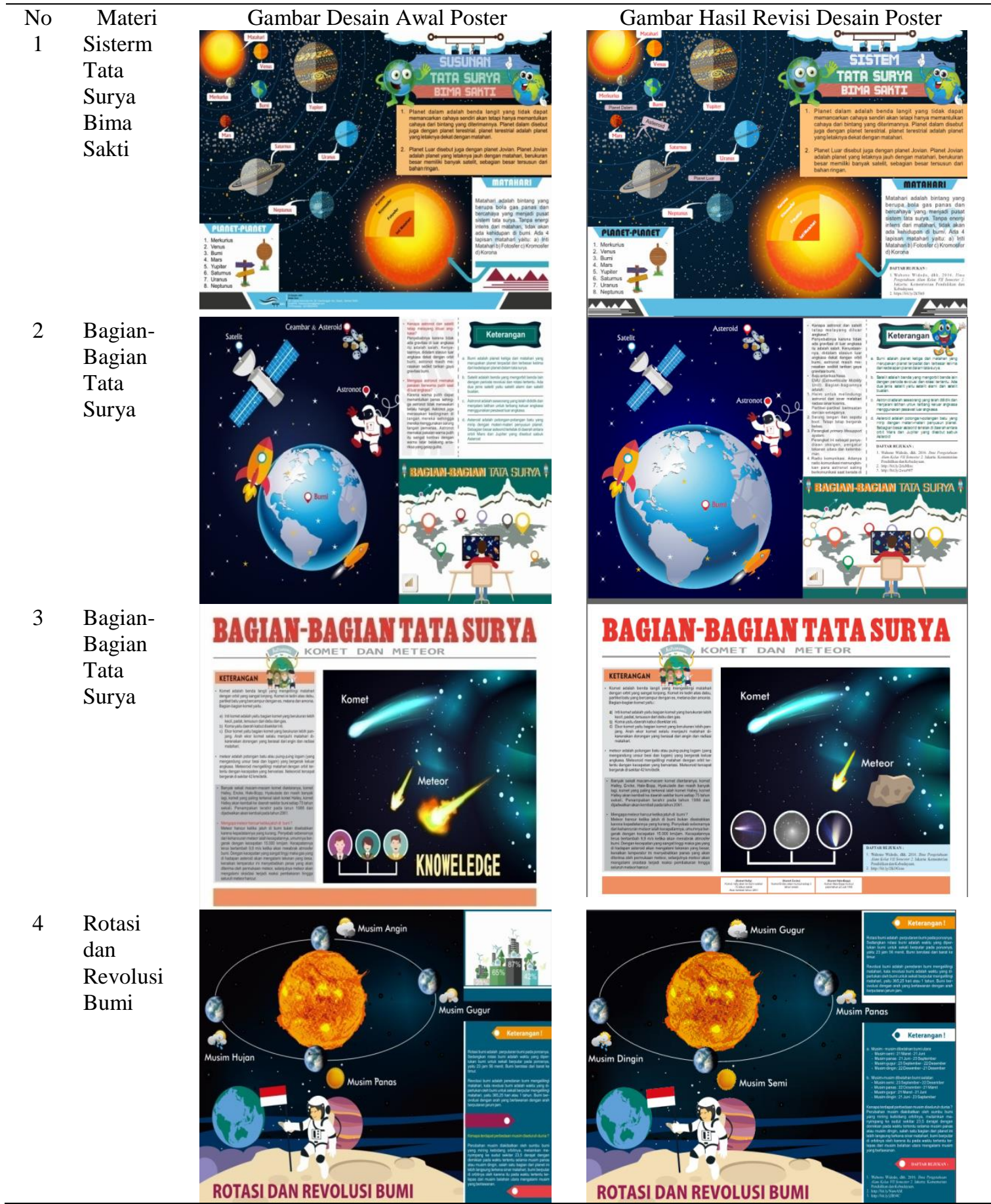




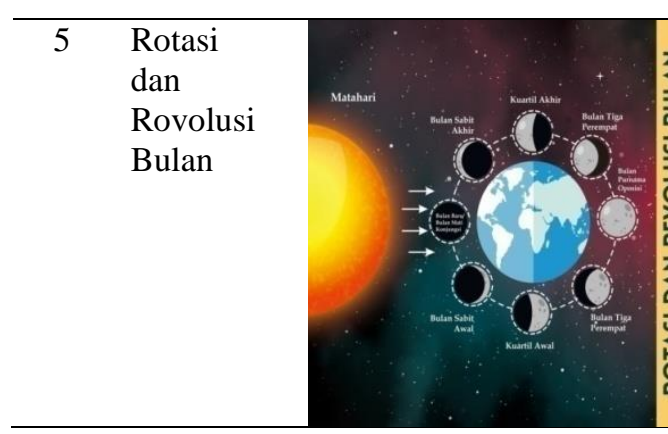

\section{Kelayakan Model}

Setelah produk telah berhasil dikembangkan langkah selanjutnya adalah melakukan uji kelayakan model dengan cara validasi produk. Validasi desain atau produk dilakukan setelah pembuatan produk awal. Validasi dilakukan dengan 2 macam, yaitu validasi ahli materi dan validasi ahli media. Sebelum melakukan validasi desain dan produk terlebih dahulu melakukan validasi instrumen penelitian oleh dosen ahli. Lembar validasi diberikan kepada 2 orang ahli materi dan 2 orang ahli media sebagai validator.

\section{a. Validasi Ahli Materi}

Produk yang dibuat kemudian divalidasi oleh validator ahli materi. Adapun aspek yang divalidasi oleh ahli materi adalah kualitas isi, kebahasaan, keterlaksanaan, tampilan visual, tampilan gambar dan kemudahan pengguna. Berikut disajikan hasil validasi produk oleh ahli materi tahap 1 dan 2.

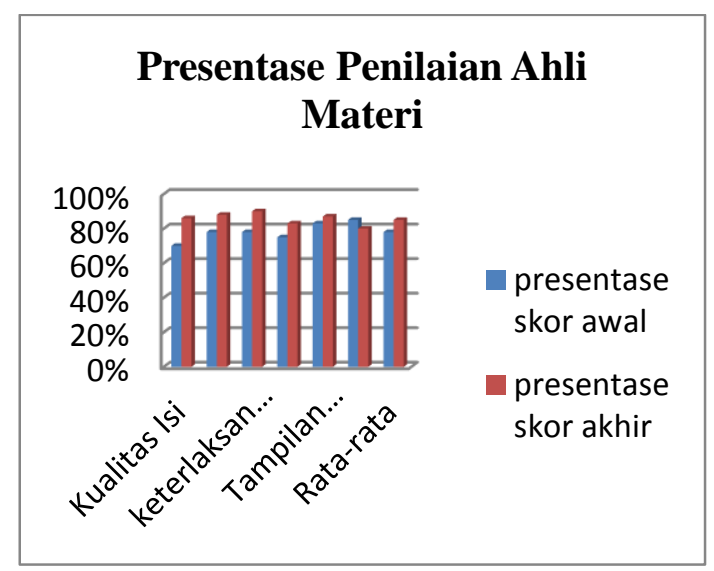

Gambar 1. Grafik Hasil Penilaian Ahli materi
Berdasarkan grafik di atas terlihat bahwa validasi ahli materi tahap 1 dan 2 yaitu kualitas isi $70 \%$ dan $86 \%$, kebahasaan $78 \%$ dan $88 \%$, keterlaksanaan $78 \%$ dan $90 \%$, tampilan visual $75 \%$ dan $83 \%$, tampilan gambar $83 \%$ dan $87 \%$ dan kemudahan pengguna $85 \%$ dan $80 \%$.

Perbedaan hasil presentase tahap 1 dan 2 dikarenakan validator menganggap bahwa media poster masih ada kekurangan dan perlu ditambah sehingga poster akan terlihat lebih menarik.

\section{b. Validasi Ahli Media}

Produk yang dibuat kemudian divalidasi oleh validator ahli media. Adapun aspek yang divalidasi oleh ahli media adalah kualitas isi, kebahasaan, keterlaksanaan, tampilan visual, aspek gambar dan kemudahan pengguna. Berikut disajikan hasil validasi produk oleh ahli materi tahap 1 dan 2.

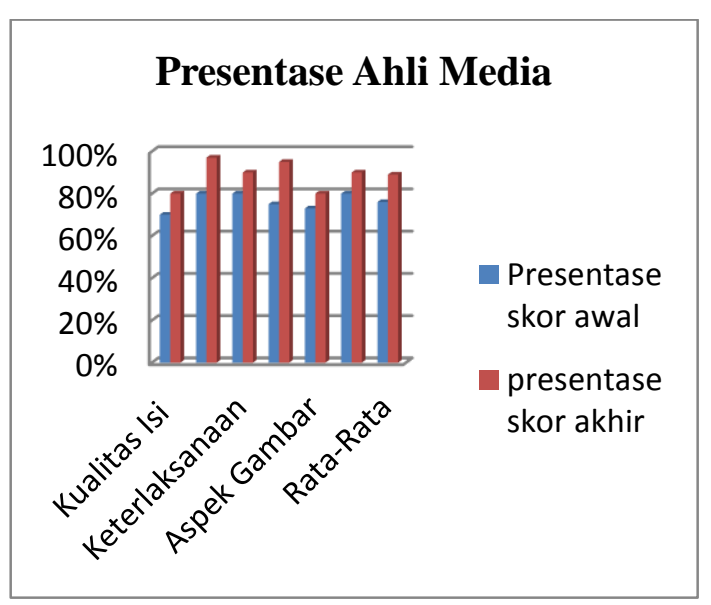

Gambar 2. Grafik Hasil Penilaian Ahli media 
Berdasarkan grafik di atas terlihat bahwa validasi ahli media tahap 1 dan 2 yaitu kualitas isi $70 \%$ dan $80 \%$, kebahasaan $80 \%$ dan $97 \%$, keterlaksanaan $80 \%$ dan $90 \%$, tampilan visual $75 \%$ dan $95 \%$, aspek gambar $73 \%$ dan $80 \%$, kemudahan pengguna $80 \%$ dan $90 \%$.

\section{Revisi Desain}

Produk yang sudah diberi penilaian oleh para ahli selanjutnya direvisi. Revisi dilakukan berdasarkan saran dan komentar yang diberikan ahli selama proses validasi. Beberapa poin dari aspek yang direvisi adalah sebagai berikut:

a. Perbaikan Instrumen

b. Perbaikan Ilustrasi Gambar

c. Perbaikan Penjelasan Materi/Konten

Ketiga poin tersebut kemudian dijadikan dasar untuk diperbaiki. Namun, terlepas dari perbaikan tersebut, secara umum para ahli telah sepakat bahwa produk pengembangan dinyatakan sudah layak untuk digunakan dengan sedikit perbaikan.

\section{Uji coba produk}

Produk yang telah direvisi sesuai dengan saran ahli kemudian di uji cobakan ke pendidik dan peserta didik. Berikut disajikan grafik penilaian dari penggunaan produk, dalam hal ini adalah uji coba lapangan dan guru mata pelajaran fisika.

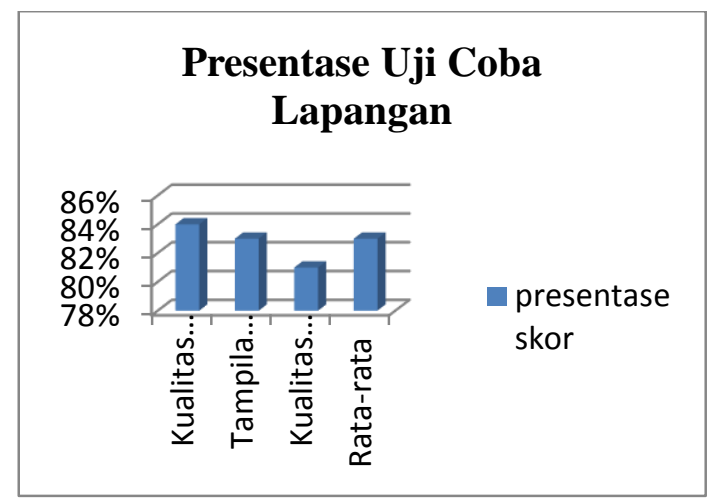

Gambar 3. Grafik Hasil Penilaian Uji Coba Lapangan
Berdasarkan grafik di atas terlihat bahwa hasil penilaian kualitas isi $84 \%$, tampilan media $83 \%$, kualitas teknis $81 \%$ dan rata-rata $83 \%$.

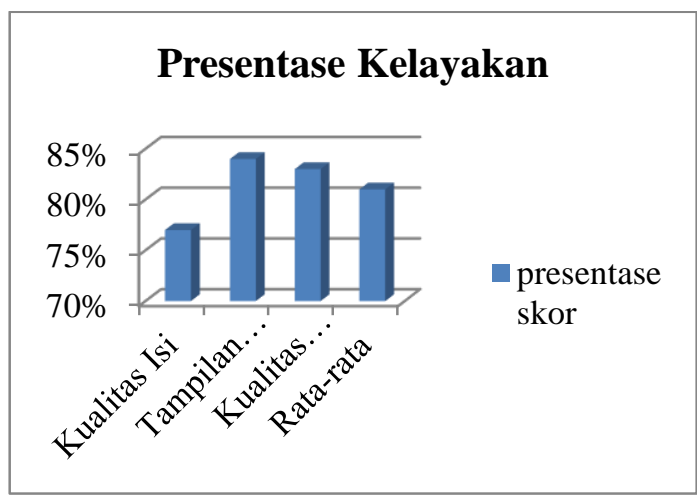

Gambar 4. Grafik Presentase Kelayakan

Berdasarkan grafik di atas terlihat bahwa hasil penilaian kualitas isi $77 \%$, tampilan media 84\%, kualitas teknis $83 \%$ dan rata-rata $81 \%$.

Berdasarkan komentar yang diberikan pengguna, diberikan kesimpulan bahwa mereka membutuhkan media pembelajaran seperti ini guna menunjang pembelajaran fisika dikelas.

\section{Pembahasan}

Tahapan awal dalam perencanaan produk awal adalah melakukan observasi kesekolah-sekolah. Hasil dari observasi yang dilakukan diketahui bahwa belum digunakannya media pembelajaran berupa poster dalam proses pembelajaran dan dibutuhkan dalam pembelajaran. Langkah awal dalam pembuatan media poster diawali dengan mencari materi dan gambar yang sesuai untuk mendesain poster tersebut dan mencari perpaduan warna yang cocok dengan materi dan gambar yang digunakan.

Produk tersebut diharapkan dapat menjadi dasar dalam mengembangkan media poster. Media poster merupakan salah satu media pembelajaran yang dapat digunakan pendidik dalam melaksanakan kegiatan pembelajaran dan peserta didik dapat lebih mudah 
memahami konsep pembelajaran dengan baik.

\section{SIMPULAN DAN SARAN Simpulan}

Pengembangan media poster sebagai media pembelajaran fisika memiliki karakteristik yaitu sangat praktis digunakan, dibuat dengan cara mencari materi tata surya terlebih dahulu lalu mencari gambar yang sesuai dengan materi dan menggabungkan warna yang tepat untuk media poster. Dapat diketahui juga bahwa produk memiliki kualitas yang baik dari segi materi dan media, serta penilaian guru fisika terhadap produk bahwa kualitasnya telah baik sehingga dapat menjadi media pembelajaran. Jadi secara keseluruhan menunjukkan bahwa media poster memiliki kualitas yang baik, sangat praktis dan dapat digunakan untuk menjadi media pembelajaran fisika. Pengembangan poster materi tata surya layak digunakan dalam pembelajaran berdasarkan hasil validasi para ahli. Hasil uji coba yang dilakukan kelompok kecil dari tiga sekolah mendapatkan persentase kelayakan rata-rata $82 \%$ dengan kategori sangat menarik. Pada uji coba lapangan yang dilakukan yang dilakukan di tiga sekolah mendapatkan presentase kelayakan rata-rata sebesar $83 \%$ dengan kategori sangat menarik.

\section{DAFTAR PUSTAKA}

Anggareni, W., Ristiati, N. P., \& Widiyanti. (2013). Implementasi Strategi Pembelajaran Inkuiri terhadap Kemampuan Berpikir Kritis dan Pemahaman Konsep IPA Siswa SMP. Jurnal Program Pascasarjana Universitas Pendidikan Ganesha, 3(1), 1-11.

Arsyad, A. (2013). Media Pembelajaran. Jakarta: Raja Grafindo Persada.

Jannah, F. Z., Serevina, V., \& Astra, I. M.
(2016). Pengembangan Media Pembelajaran Poster Fisika Fluida Statis Berbasis Lingkungan Dalam Bentuk Poster Photoscrap. Prosiding Seminar Nasional Fisika (E-Journal) SNF2016, V.

Latifah, S. (2015). Pengembangan Modul IPA Terpadu Terintegrasi AyatAyat Al-Qur'an Pada Materi Air Sebagai Sumber Kehidupan. Jurnal Ilmiah Pendidikan Fisika AlBiRuNi, 4(2).

Mayena, S. (2013). Pengembangan Media Poster Berbasis Pendidikan Karakter Untuk Materi Global Warming. Jurnal Materi Dan Pembelajaran Fisika (JMPF), 3(1).

Nurfajriyah, D., Aeni, A. N., \& Jayadinata, A. K. (2016). Pengaruh Model Problem Based Learning Terhadap Kemampuan Berpikir Kreatif Siswa Pada Materi Pesawat, 1(1), 251-260.

Putri, N. W. M. A., Jampel, N., \& Suartama, I. K. (2014). Pengembangan E-Learning Berbasis Schoology Pada Mata Pelajaran Ipa Kelas VIII Di SMP Negeri 1 Seririt. Journal Edutech Universitas Pendidikan Ganesha, Jurusan Teknologi Pendidikan.

Rizawayani, Sari, S. A., \& Safitri, R. (2017). Pengembangan Media Poster Pada Materi Struktur Atom Di SMA Negeri 12 Banda Aceh. Jurnal Pendidikan Sains Indonesia, 5(1), 127-133.

Sadiman, A. S., \& Dkk. (2012). Media Pendidikan Pengertian,

Pengembangan dan

Pemanfaatannya. Jakarta: Raja Grafindo Persada.

Sanjaya, W. (2017). Penelitian

Pendidikan: Jenis, Metode dan Prosedur (Pertama). Jakarta: Kencana.

Sugiyono. (2016). Metodologi Penelitian Pendidikan: Pendekatan Kualitatif, Kuantitatif, dan $R \& D$. Bandung: 
Alfabeta.

Susilo, M. J. (2015). Analisis Kualitas

Media Pembelajaran Insektarum

dan Herbarium untuk Mata

Pelajaran Biologi Sekolah

Menengah. Jurnal Bioedukatika, $3(1)$.

Wena, M. (2012). Stratregi

Pembelajaran Inovatif

Kontemporer. Jakarta: Bumi

Aksara.

Widayanti, W., \& Yuberti, Y. (2018).

Pengembangan Alat Praktikum

Sederhana sebagai Media Praktikum

Mahasiswa. JIPFRI (Jurnal Inovasi

Pendidikan Fisika Dan Riset

Ilmiah), 2(1), 21-27. 